УДК 343.9

DOI https://doi.org/10.32849/2663-5313/2020.3.48

Михайло Балан,

заступник військового прокурора Західного регіону Украйни,

здобувач

Національної академії Державної прикордонної служби Украӥни

імені Богдана Хмельнииького

\title{
ВЗАЄМОДІЯ СЛІДЧОГО ТА ІНШИХ СУБ’ЄКТІВ КРИМІНАЛЬНОГО ПРОВАДЖЕННЯ ПРИ РОЗСЛІДУВАННІ ПОРУШЕНЬ ДЕРЖАВНОГО КОРДОНУ УКРАЇНИ
}

Стаття присвячена дослідженню окремих питань взаємодї слідчого та інших суб'єктів кримінального провадження під час розслідування порушень державного кордону Украйни. Констатовано, що взаємодія у діяльності слідчого відіграє важливу роль у вирішенні завдань кримінального провадження. Сформульовано поняття взаємодії слідчого з іншими суб'єктами кримінального провадження. Визначено особливості, які впливають на організачію взаємодії під час проведення огляду місия події у разі порушеннія державного кордону. Констатовано, шо огляд місия події як слідча дія потребує додаткового регулювання у КПК України та наділення оперативних підрозділів повноваженнями на його проведення до внесення відомостей у ЄРДР. Внесена пропозиція щодо певних обмежень у наданні доручень оперативним підрозділам та шодо ї̈ закріплення у КПК України. За підсумками дослідження запропоновано внесення низки змін до законів та підзаконних нормативно-правових актів, які привели б у відповідність до потреб практики нормативно-правове регулювання взаємодї слідчого з іншими учасниками розслідування порушень державного кордону, а також зазначено необхідність ї̈ включення у криміналістичну тактику та у методику розслідування злочинів, у тому числі пов'язаних з порушенням ДКУ. Запропоновано у новій редакції Інструкиї з організаиії взаємодії органів досудового розслідування з іншими органами та підрозділами Національної поліиії України у запобіганні кримінальним правопорушенням, їх виявленні та розслідуванні (Наказ МВС України від 07.07.2017 № 575) передбачити розділ щодо особливостей організаиії взаємодії під час розслідування злочинів, пов'язаних із посяганням на недоторканість ДКУ. Визнано, що низка змін у чинному законодавстві потребує коригування криміналістичного забезпечення взаємодії слідчого (прокурора) під час розслідування з іншими учасниками розслідування. За підсумками дослідження окреслено напрями подальших наукових розробок, які мають сприяти ефективній протидї̈ злочинності на ДКУ.

Ключові слова: розслідування порушень державного кордону, взаємодія слідчого з іншими учасниками кримінального провадження, слідча група, слідчо-оперативна група, доручення слідчого, огляд місця події.

Постановка проблеми. Ефективність розкриття, розслідування та попередження злочинів значною мірою залежить від успішності взаємодії слідчого з іншими учасниками цього процесу - оперативними працівниками, працівниками інших служб правоохоронних органів, спеціалістами та експертами, контрольно-ревізійними органами, засобами масової інформації [1, с. 491].

Окремі питання взаємодії під час розслідування порушень державного кордону України були предметом дослідження низки вчених, однак аналіз наукових джерел свідчить, що на етапі становлення України як самостійної незалежної держави, особливо в умовах суттєвих змін у законодавстві протягом останнього десятиліття, загострення воєнно-політичної обстановки, питанню взаємодії під час розслідування порушень ДКУ на монографічному рівні увага не приділена [2-6]. У зв'язку з цим є нагальна потреба у розгляді окремих аспектів взаємодії у діяльності слідчого, які визначаються особливостями розслідування посягань на недоторканність ДКУ.

Аналіз останніх досліджень і публікацій. Проблеми організації взаємодії між органами досудового слідства та іншими учасниками розслідування були предметом наукових досліджень Ю. П. Аленіна, В. П. Бахіна, Р.С.Бєлкіна,А.Ф.Волобуєва, В.Г.Гончаренка, А. В. Іщенка, В. О. Коновалової, В. П. Корж, В. С. Кузьмічова, Є. Д. Лук'янчикова, M. А. Погорецького, М. В. Салтевського, В. В. Тіщенка, Г. П. Цимбал, П. В. Цимбала, Ю. М. Чорноус, В. Ю. Шепітька та інших вчених [7-10]. На монографічному рівні після прийняття КПК України 2012 року дослідженню проблемних питань взаємодії слідчих присвятили свої роботи I. М. Єфіменко, 
В. М. Малюга, В. В. Топчій, С. В. Яковчук та інші вчені [11-14].

Метою статті є представлення результатів аналізу нормативно-правового регулювання та криміналістичного забезпечення взаємодії слідчого 3 іншими учасниками кримінального провадження та її особливостей під час проведення огляду місця події у процесі ॥ розслідування порушень ДКУ.

Виклад основного матеріалу. Поняття «взаємодія» як складний вид діяльності дає змогу класифікувати форми взаємодії слідчого з учасниками кримінального провадження. Серед різновидів взаємодії насамперед звертаємо увагу на її класифікацію за нормативно-правовою регламентацією: процесуальні форми (передбачені КПК України); непроцесуальні (організаційно-правові) форми (передбачені законами України (3У) та підзаконними нормативно-правовими актами (ПНА); суто організаційні форми (розроблені наукою та практикою).

Натепер є кілька підходів щодо визначень процесуальної форми взаємодії. Одні автори вважають такою формою взаємодії закріплені кримінальним процесуальним законом способи співпраці суб'єктів у процесі розслідування злочинів, інші - також способи, які додатково регулюються ще й іншими НПА у сфері діяльності правоохоронних органів, у тому числі підзаконними Ми вважаємо, що заслуговує на увагу позиція тих вчених, які відносять до процесуальних форм взаємодії ті, які передбачені КПК України. Вони можуть бути детально регламентовані нормами КПК або тільки зазначені у КПК з подальшою регламентацією в інших ЗУ/ПНА чи взагалі без подальшої додаткової нормативно-правової регламентації. А непроцесуальні (організаційні) форми взаємодії - це ті, які врегульовані відомчими НПА (наказами, інструкціями, вказівками тощо) та нормами службової етики, які сформовані практикою [15, с. 190].

Однак, на нашу думку, усі форми взаємодії, незалежно від виду НПА за юридичною силою, якими вони регулюються, здійснюються у рамках кримінально-процесуальних правовідносин у зв'язку з конкретним кримінальним провадженням, за межами якого вони не існують, за певним незначним винятком (ОМП до внесення відомостей в СРДР (ч. 3 ст. 214 КПК), законне затримання (ст. 207 КПК та) та ін.). У зв'язку з цим пропонуємо форми взаємодії, які закріплені у КПК України, визначити як «основні», а ті, які, регулюються ПНА, - «додаткові/ допоміжні». Додаткові форми взаємодії передбачають організаційні заходи та засоби їх реалізації і спрямовані на забезпечення узгодженої та цілеспрямованої діяльності слідчого з іншими суб'єктами у межах кримінального провадження. Дане питання, на нашу думку, може бути предметом окремої наукової дискусії.

Однією 3 найбільш раціональних організаційно-тактичних форм взаємодії у рамках координації діяльності під час розслідування, як відзначають Ю. П. Аленін та М. А. Погорецький, $є$ створення слідчо-оперативних груп $[16 ; 17]$.

Нормативне визначення понять «слідча група» (СГ) і «слідчо-оперативна група» (СОГ) закріплено у низці наказів МВС України. Так, у наказі МВС України від 20.10.2014 № 1107 «Про затвердження Інструкції про порядок створення та організації діяльності СГ та СОГ» (втратив чинність з 2017 року) СГ визначено як передбачену КПК України організаційну форму здійснення двома чи більше слідчими досудового розслідування у кримінальному провадженні, а СОГ - як організаційну форму взаємодії слідчих та працівників оперативних підрозділів ОВС України, що полягає у здійсненні досудового розслідування слідчим (декількома слідчими) та за його (iх) письмовим(и) дорученням(и) здійснення С(Р)Д та НС(Р)Д працівниками оперативних підрозділів ОВС України у кримінальному провадженні, яке знаходиться у провадженні слідчих підрозділів ОВС України [18].

У наказі МВС України від 16.02.2018 № 111 «Про затвердження Інструкції з організації реагування на заяви та повідомлення про кримінальні, адміністративні правопорушення або події та оперативного інформування в органах (підрозділах) НПУ » вказано, що СОГ - це організаційна форма взаємодії слідчих (дізнавачів), працівників оперативних та інших підрозділів поліції з метою виявлення, фіксації, вилучення та пакування слідів кримінального правопорушення, речових доказів, установлення свідків та потерпілих, з'ясування обставин кримінального правопорушення, що мають значення для всебічного, повного і неупередженого їх дослідження та встановлення осіб, які його вчинили [19].

Аналіз понять СОГ у вказаних НПА свідчить про різні підходи щодо їх учасників, форм взаємодії між ними та їх мети.

СОГ як суб'єкт кримінального провадження не визначена на законодавчому рівні у КПК України, а тому ми розділяємо позицію тих авторів [20, с. 49], які вважають, що СОГ не $\epsilon$ формою провадження досудового розслідування, а являє собою лише форму взаємодії слідчого з працівниками оперативних 
підрозділів, яка суттєво відрізняється від надання доручень (ст. 41 КПК України).

СГ/СОГ виступають стороною кримінального провадження (на стороні обвинувачення) та уповноважені на проведення СРД, результати яких можуть використовуватись у кримінальному провадженні як докази, а тому, на нашу думку, є усі підстави для закріплення їх понять у новій редакції ст. 3 КПК України «Визначення основних термінів Кодексу».

Аналіз практики розслідування порушень ДКУ свідчить про певні особливості нормативно-правового і криміналістичного аспектів та наявність проблем у функціонуванні СОГ.

Серед різноманітних форм взаємодії під час розслідування порушень ДКУ найбільше значення, за опитуваннями слідчих НПУ/СБУ, має надання доручень відповідним оперативним підрозділам (67 \% / $71 \%)$ та використання СОГ (73\% / $76 \%)$.

В Інструкції (Наказ МВС 07.07.2017 № 575), у пп. 9-15, визначено особливості організації взаємодії під час розслідування певних різновидів кримінальних правопорушень, зокрема, вчинених проти життя, здоров'я, статевої свободи та статевої недоторканості особи, під час розслідування дорожньо-транспортних пригод, кримінальних правопорушень, пов'язаних із незаконним обігом наркотичних засобів, психотропних речовин, їх аналогів або прекурсорів та ін. Вказана Інструкція прийнята після передачі у 2015 році підслідності ст. 332 КК України від слідчих СБУ слідчим НПУ, а тому вона мала б, на нашу думку, включати відповідний розділ, у якому б визначались особливості організації взаємодії під час розслідування злочинів, пов'язаних із посяганням на недоторканність ДКУ. Однак особливості нормативно-правового регулювання діяльності СОГ під час розслідування порушень ДКУ на підзаконному рівні не врегульовані, що відповідно не сприяє розробці відповідного їх криміналістичного забезпечення.

Найбільш поширеними формами взаємодії, що визначені у КПК України, $\epsilon$ письмові доручення на проведення СРД та НСРД (ч. 1 ст. 41 КПК) прокурора (п. 5. ч. 2. ст. 36 КПК) та слідчого (п. 3. ч. 2. ст. 40 КПК) оперативним підрозділам; доручення (вказівки) прокурора (п. 4 ч. 2 ст. 36, ч. 4 ст. 40 КПК) слідчому.

До новел КПК України можна віднести визначення нового суб'єкта кримінальнопроцесуальної діяльності - оперативного підрозділу, який входить до визначеного ч. 1 ст. 41 КПК України переліку органів; наділення співробітника оперативного під- розділу повноваженнями слідчого під час виконання доручень слідчого, прокурора (ч. 2 ст. 41 КПК України).

У дорученнях слідчого згідно 3 п. 5 p. VI Інструкції (Наказ МВC від 07.07.2017 № 575) зазначаються: найменування кримінального провадження, його реєстраційний номер та дата початку досудового розслідування; правова кваліфікація кримінального правопорушення із зазначенням статті (частини статті) КК України; короткий виклад фактичних обставин кримінального правопорушення; конкретний перелік СРД /НСРД які потрібно виконати, та інші відомості, які необхідні для виконання цих дій. Виконання доручень слідчих повинно здійснюватися у строки, які зазначені у дорученнях. У разі неможливості своєчасного виконання доручення продовження строку його виконання письмово погоджується зі слідчим, який дав доручення (п. 6 р. VI Інструкції).

Як свідчить практика, під час розслідування порушень ДКУ слідчі НПУ значною мірою використовують взаємодію у формі надання доручень оперативним підрозділам ДПСУ.

Так, оперативними підрозділами ДПСУ від національних правоохоронних органів було отримано на проведення СРД та НСРД у 2013 р. 6281 доручення, 3 яких виконано 6249 , у 2014 р. - 9156 доручень (виконано 8 901), у 2017 році отримано на проведення понад 9300 доручень, 87,9 \% 3 яких виконано. Збільшилась кількість доручень на проведення НСРД (2016 р. - 126, 2017 р. - 145). Досить широкою є приналежність доручень і до різних правоохоронних органів. Так, оперативними підрозділами ДПСУ було виконано у 2016 році 9745 доручень, у 2017 році від органів НПУ надійшло 5733 доручення (виконано - 5 063); від СБУ - 1288 (1 108); від органів прокуратури різного рівня - 1812 (1 623); ДФС 519 (431); НАБУ - 22 (20) [21].

Однак форма i зміст доручень не завжди відповідають вимогам положень п. 3 ч. 2 ст. 40 КПК України і викликають неоднозначні думки практиків. Аналіз взаємодії слідчих, прокурорів з оперативними підрозділами ДПСУ свідчить, що, формулюючи у дорученні завдання, слідчі не завжди дотримуються вимог КПК України про те, що доручення може стосуватись лише проведення СРД/НСРД (п. 3 ч. 2 ст. 40 та ч. 1 ст. 41 КПК України). Натомість мають місце доручення щодо виконання заходів, які не належать до СРД/НСРД, зокрема: «здійснити оперативно-розшукову діяльність 3 метою встановлення осіб, які вчинили кримінальне правопорушення», «здійснити заходи 3 метою 
встановлення фактичних обставин вчинення кримінального правопорушення»; «одержати в уповноважених установах установчі дані та документи на конкретних осіб»; «забезпечити виклик особи та вручити повістку про виклик»; «встановити факти в'їздувиїзду через державний кордон осіб, транспортних засобів та надати інформацію про це»; «зібрати характеризуючий матеріал на особу», «витребувати документи» тощо [4]; «відібрати зразки дата-штампів, отримати та надати копії документів підприємств, установ та організацій»; «провести інші необхідні розшукові та процесуальні дії для встановлення об'єктивної істини та притягнення винних осіб до відповідальності»; «встановити, які сім-карти вставлялись в телефонну слухавку підозрюваного до затримання»; перевірити осіб по обліках УІТ ГУ МВС України (СРДР № 22012150000000009); забезпечити явку осіб у слідчий підрозділ (СРДР № 220120700000017); у дорученні в рамках досудового розслідування (СРДР № 22012070000000023) вказано завдання на проведення комплексу оперативно-розшукових заходів на встановлення осіб, причетних до вчинення злочину, будинків (адресу тимчасового проживання) тощо у регіонах України за межами ділянки прикордонного загону.

КПК України не передбачає обмежень щодо СРД/НСРД, які можуть бути доручені відповідному оперативному підрозділу, водночас не наділяє слідчого повноваженнями доручати проведення інших процесуальних дій, а також вимагати допомоги у проведенні окремих слідчих дій (на відміну від повноважень слідчого згідно з ч. 3 ст. 114 КПК України 1960 р.).

На думку С. М. Стахівського, є неприпустимим доручати оперативним підрозділам виконання таких слідчих (розшукових) дій, які зумовлюють або визначають напрям досудового розслідування, вказують на оцінку доказів [22, с. 121]. А тому, на нашу думку, у п. $3^{1}$ ч. 2 ст. 40 КПК України доцільно викласти не перелік СРД, виконання яких слідчому заборонено/може бути заборонено доручати виконувати оперативним підрозділам, а перелік умов (обставин), за яких він це не може зробити, зокрема: у разі проведення СРД 3 участю малолітніх/неповнолітні/ душевнохворих, представників дипломатичних представництв, на об'єктах критичної інфраструктури та ін. У разі надання такого доручення воно має бути обгрунтоване та узгоджене із прокурором/слідчим суддею.

«Інструкцією з організації взаємодії органів досудового розслідування з іншими органами та підрозділами Національної поліції України в запобіганні кримінальним право- порушенням» визначено вимоги щодо змісту доручення: найменування кримінального провадження, його реєстраційний номер; правова кваліфікація кримінального правопорушення; короткий виклад фактичних обставин кримінального правопорушення; конкретний перелік СРД та НСРД, які потрібно виконати, та ін.

Для досягнення мети доручення, недопущення формального ставлення до його виконання, на нашу думку, у дорученні доцільно додатково вказати певні криміналістичні рекомендації, які можуть (мають) бути враховані під час виконання доручення, а також доцільність додаткової фіксації його виконання за допомогою техніко-криміналістичних засобів.

Це дасть можливість слідчому більш об'єктивно оцінити якість виконання доручення та його результати. Відповідне доповнення доцільно передбачити у пп.5 п. 6 вказаної Інструкції.

Ст. 214 КПК передбачає лише один можливий варіант реагування уповноважених органів на отримання заяви (повідомлення) про кримінальне правопорушення - це внесення відомостей до Єдиного реєстру досудових розслідувань (ЄРДР). При цьому слідчим (прокурором) має бути здійснена попередня правова кваліфікація кримінального правопорушення із зазначенням статті (iï частини) ККУ. На практиці не завжди відомості, які викладені у заяві (повідомленні) про порушення ДКУ, можуть бути оцінені як такі, що вказують на ознаки злочину. Однак законодавець передбачив у КПК України єдиний засіб перевірки заяви (повідомлення) про кримінальне правопорушення - це огляд місця події (ОМП), який у невідкладних випадках може бути проведений до внесення відомостей до СРДР, що здійснюється негайно після завершення огляду (ч. 3 ст. 214 КПК України).

Аналіз практики розслідування порушень ДКУ дає підстави визначити певні особливості та проблеми щодо взаємодії, які пов'язані, зокрема, із проведенням ОМП. Незаконні перетинання ДКУ можуть бути кваліфіковані як адміністративні делікти (ст. 2014-1 КУпАП) і як кримінальні правопорушення (ст. 332, 332-2 ККУ). При цьому адміністративне провадження здійснюють органи охорони державного кордону України, а розслідування злочинів, передбачених ст. 332 ККУ, - слідчі НПУ, ст. 332-2 ККУ слідчі СБУ. До особливостей, які прямо (опосередковано) впливають на організацію взаємодії під час проведення ОМП, доцільно віднести те, що ОМП як слідча дія у ст. 214, 237 КПК України не закріплена; 
у разі порушення ДКУ в умовах неочевидності одночасно з проведенням ОМП, як правило, ООДКУ проводиться пошук і затримання порушників по «гарячих слідахм», а тому ОМП доцільно проводити із залученням складу прикордонного наряду (адміністративної групи), які припиняли (виявили ознаки) порушення ДКУ, та оперативних працівників ООДКУ; у разі проведення ОМП за межами прикордонної смуги - додатково із залученням оперативних працівників НПУ; необхідність залучення інспектора (техніка)криміналіста та кінолога із службовою собакою - у разі виявлення ознак порушення ДКУ значною кількістю порушників, ознак організації (пособництва) порушення ДКУ, силового затримання порушників із застосуванням зброї (спецзасобів), виявлення транспортних засобів (малої авіації, БПЛА); у разі виявлення під час ОМП ознак злочину, передбаченого ст. 332-2 ККУ, доцільно направляти повідомлення та проводити ОМП у взаємодії зі слідчим СБУ; у разі виявлення під час порушення ДКУ ознак злочинів, передбачених статтями ККУ різної підслідності, ОМП доцільно проводити спільною СГ/СОГ (НПУ, СБУ, ДФС).

Більшість кримінальних справ про порушення ДКУ до набрання чинності КПК України 2012 року розслідувалась органами дізнання ДПСУ, до 2015 року - слідчими СБУ, а нині - слідчими НПУ. Такі зміни підслідності вимагають і відповідного коригування криміналістичного забезпечення.

Тлумачення ст. 41 КПК України дає підстави вважати, що окреме доручення слідчого (прокурора) оперативному підрозділу на проведення СРД/НСРД може надаватись лише у кримінальному провадженні, тобто після внесення відомостей у СРДР. Однак, оскільки ОМП згідно 3 ч. 3 ст. 314 КПК України може проводитись і до початку кримінального провадження (внесення відомостей у СРДР), доцільно у новій редакції ст. 41 КПК України закріпити таке положення: «письмове доручення слідчого, прокурора щодо проведення огляду місця події може надаватись відповідним оперативним підрозділам до початку кримінального провадження».

\section{Висновки}

На нашу думку, взаємодія слідчого з іншими суб'єктами кримінального провадження являє собою унормовану, криміналістично забезпечену діяльність, що зумовлена слідчою ситуацією та спрямована на залучення слідчим (прокурором) у конкретному кримінальному провадженні інших суб'єктів, які у межах визначених повнова- жень сприяють слідчому (прокурору) у вирішенні завдань кримінального провадження.

Взаємодія слідчого з іншими учасниками кримінального провадження потребує додаткового нормативно-правового врегулювання у КПК України та у підзаконних нормативноправових актах, має бути включена у криміналістичну тактику та у методику розслідування злочинів, у тому числі пов'язаних з порушенням ДКУ, потребує розробки належного криміналістичного забезпечення.

Особливості сучасних загроз національній та прикордонній безпеці, ускладнення воєнно-політичної обстановки, спричиненої «гібридною війною» РФ проти України, свідчить про те, що посягання на недоторканність ДКУ «модифікуються», набуваючи жорстких форм, нейтралізація яких потребує відповідного реагування на рівні нормативно-правового та криміналістичного забезпечення суб'єктів такої протидії.

\section{Список використаних джерел:}

1. Криминалистика : учебник / Аверьянова Т.В. и др. ; под ред. Р.С. Белкина. Москва : HOPMA, 2001.990 c.

2. Балан М.В., Літвін Ю.І. Особливості взаємодії при проведенні огляду місця події під час розслідування порушень державного кордону. Досудове розслідування: актуальні проблеми та шляхи їх вирішення : матеріали наук.-практ. конф., м. Харків, 25 жовт. 2019 р. Харків : Право, 2019. С. 8-12.

3. Літвін Л.Ю., Мельник Г.В. Взаємодія органів охорони державного кордону України з органами безпеки при розслідуванні порушень державного кордону України. Спільні дії військових формувань і правоохоронних органів держави : проблеми та перспективи : збірник тез доповідей між нар. наук.-практ. конф., м.Одеса 12-13 вересня 2019 р. Одеса. 2019. С. 431-432.

4. Сорока А., Корольов В.О. Виконання доручень слідчого оперативними підрозділами Держприкордонслужби України. Вісник Національноі академії Державної прикордонної служби України. Серія «Юридичні науки». 2018. Вип. 1. URL: http://nbuv.gov.ua/UJRN/vnadpcurn_2018 1_5 (дата звернення: 17.01.2020).

5. Сич В.О. Методика розслідування злочинів, пов'язаних з порушенням державного кордону : автореф. дис. ... канд. юрид. наук: 20.02.03. Хмельницький, 1998. 17 с.

6. Капітанчук Л.Ю. Особливості розслідування нелегальної міграції : дис. ... канд. юрид. наук : 12.00 .09 . Київ, 2011. 250 с.

7. Чорноус Ю.М. Особливості взаємодії при розслідуванні злочинів міжнародного характеру. Вісник Луганського державного університету внутрішніх справ імені Е.О. Дідоренка. 2012. Вип.1. С. 231-238. URL: http:// nbuv.gov.ua/UJRN/Vlduvs_2012_1_29 (дата звернення: 18.01.2020). 
8. Юхно О.О. Окремі аспекти взаємодії слідчих та інших підрозділів органів внутрішніх справ при розслідуванні злочинів. Вісник Харківського національного університету внутрішніх справ. 2012. № 2. C. 212-221.

9. Цимбал П.В., Власова Г.П. Поняття взаємодії таїі основні ознаки. Взаємодія оперативнихта слідчих підрозділів при розслідуванні злочинів у сфері господар ської діяльності : матеріали міжнар. постійно діючого наук.-практ. семінару. Ірпінь, 2009. С. 454-464.

10. Цимбал Г.П. Взаємодія як умова забезпечення виявлення і розслідування податкових злочинів : автореф. дис.... канд. юрид. наук : 12.00.09. Київ, 2005.19 с

11. Малюга В.М. Взаємодія слідчого з оперативними підрозділами та іншими суб'єктами в системі методики розслідування злочинів : автореф. дис. ... канд. юрид. наук : 12.00.09. Львів, 2016. 17 с.

12. Єфіменко I.M. Взаємодія слідчих і оперативних підрозділів при реалізації таємної інформації : автореф. дис. ... канд. юрид. наук : 12.00.09. Київ, 2014. 20 с.

13. Яковчук С.В. Взаємодія слідчого $з$ оперативними підрозділами під час розслідування серійних вбивств : автореф. дис. ... канд. юрид. наук : 12.00.09. Київ, 2014. 20 с.

14. Бойко О.П. Взаємодія слідчих Національної поліції України з підрозділами карного розшуку на досудовому провадженні : монографія. Дніпро, 2018.180 c.

15. Борисенко М.В., Мельник О.В. Взаємодія слідчого 3 іншими посадовими особами та підрозділами Національної поліції під час кримінального провадження: загальна характеристика. Науковий вісник публічного та приватного права. 2017. Вип. 5. Том 1. С. 188-191.

16. Погорецький М.А. Незаконне переправлення осіб через державний кордон: проблемні питання оперативно-розшукового документу- вання та досудового розслідування. Проблеми теорії та практики реалізаиї̈ правоохоронних функиій в охороні державного кордону : матеріали всеукр. наук.-практ. конф., Хмельницький 22-23 лист. 2007 р. Хмельницький, 2007. С. 223-227.

17. Аленін, Ю.П. Теоретичні та практичні основи розкриття і розслідування осередків злочинів : автореф. дис. ... докт. юрид. наук: 12.00.09. Харків, 1997. 44 с.

18. Інструкціiя про порядок створення та організації діяльності слідчих груп та слідчооперативних груп : наказ МВС України від 20.10.2014 № 1107. (Наказ втратив чинність на підставі Наказу МВС України № 575 від 07.07.2017). URL: http://search.ligazakon.ua/1 doc2.nsf/link1/ RE26395.html (дата звернення: 18.01.2020).

19. Інструкція 3 організації реагування на заяви та повідомлення про кримінальні, адміністративні правопорушення або події та оперативного інформування в органах (підрозділах) Національної поліції України : наказ МВС України від 16.02.2018 року №111 (Із змінами, внесеними згідно з Наказами МВС України № 654 від 07.08.2019, № 856 від 11.10.2019). URL: https:// zakon.rada.gov.ua/laws/show/z0371-18\#n7 (дата звернення: 18.01.2020).

20. Юрченко А.М., Гарбовський Л.А., Башта I.I. Взаємодія слідчого з оперативними підрозділами під час кримінального провадження: актуальні проблеми та шляхи їх вирішення : монографія. 2018. 204 с.

21. Про підсумки діяльності оперативно-розшукових підрозділів Державної прикордонної служби України у 2017 році : наказ Адміністрації Державної прикордонної служби України № 93-АГ від 12.02.2018 року.

22. Джига М.В., Баулін О.В., Лук'янець C.I., Стахівський С. Провадження дізнання в Україні : навчальний посібник. Київ, 1999. 121 с.

The article is devoted to study of particular issues of interaction of the investigator and other subjects of criminal proceedings in the investigation of violations of the state border of Ukraine. It was noted that cooperation in the activities of the investigator plays an important role in solving problems of criminal proceedings. Formulated the concept of interaction of the investigator with other subjects of criminal proceedings. The features influencing the organization of cooperation in conducting the inspection of the scene in violation of the state border. It is stated that the inspection of the scene as the investigative action requires additional regulation in the code of criminal procedure and empower the operational units of the authority forit to the entry of information in eRDR. A proposal regarding certain restrictions in providing instructions to operational units and its consolidation in criminal procedure code of Ukraine. The study proposed a number of amendments in legal and sub-legal acts which would result in compliance to the needs of practice of legal regulation of interaction of the investigator with other participants in the investigation of violations of the state border, as well as the need for it is included in criminalistic tactics and methodology of investigation of crimes, including related to the violation of the civil code. Proposed in the new edition of the Instruction on the organization of interaction of bodies of preliminary investigation with other bodies and units of the National police of Ukraine in preventing a criminal offence, their identification and investigation (Order of MIA of Ukraine from 07.07.2017 No. 575) to have a section on the specifics of organization of cooperation in the investigation of crimes that infringe on the inviolability of the civil code. It is recognized that a number of changes in the current legislation needs to be adjusted as to criminal maintenance of interaction of the investigator (Prosecutor) during the investigation with other participants in the investigation. The study and proposed areas for further research, which should contribute to the effective combating of crime in the CCU.

Key words: investigation of state border violations, interaction of the investigator with other participants in criminal proceedings, investigative team, investigative - task force, commission of the investigator, location overview. 